\title{
A Thorough Scrutiny of ELT Textbook Evaluations: A Review Inquiry
}

\author{
Reza Gholami, Nooreen Noordin, Shameem Rafik-Galea \\ Faculty of Educational Studies, Universiti Putra Malaysia, 43400 UPM, Serdang, Selangor, Malaysia
}

Corresponding author: Reza Gholami, E-mail: upmreza@gmail.com

\begin{tabular}{l} 
ARTICLE INFO \\
\hline Article history \\
Received: June 10, 2017 \\
Accepted: July 29, 2017 \\
Published: July 31, 2017 \\
Volume: 5 Issue: 3 \\
\hline Conflicts of interest: None \\
Funding: None \\
\hline
\end{tabular}

\begin{abstract}
It is thoroughly agreed that English language textbooks stand amongst the foremost components in any language classrooms worldwide, being referred to as valid, beneficial and labor-saving tools to fulfill an extensive range of needs. An ELT textbook is not merely a set of sheets of paper fastened together to hinge at one side, but is the beating heart of any education system whereupon the whole learning revolves. Notwithstanding their interminable benefits, it is admitted that still the compiled textbooks, especially the ones prescribed in Educational systems have to be evaluated and assessed to confirm whether they fulfil the objectives they are meant for or not, as it is said no perfect textbook exists. Having dealt with evaluation in general, this research meticulously elaborates on textbook evaluation more specifically concluding that there is a dearth of inquiry on textbook selection and evaluation. Afterwards, this research introduces the most common approaches for evaluating ELT textbooks and materials. The paper culminates with concluding remarks and implications, hoping to shed light on how textbook evaluation is practiced worldwide.
\end{abstract}

Key words: Textbook, Textbook Evaluation, Materials, Evaluation Methods

\section{OUTLINING THE FUNCTIONS OF ELT TEXTBOOKS}

English school textbooks are reckoned to be the most relevant source of learning English worldwide (Allehyani, Burnapp, \& Wilson, 2017a; Ebadi \& Naderifarjad, 2015; Maleki, Mollaee \& Khosravi, 2014; Moghtadi, 2014), which function as a guide for learners and instructors making them engaged in practices and make both the teaching and learning activities to thrive (Margana \& Widyantoro, 2017). Jamalvandi (2014) bring to light that textbooks hold a paramount status as an indispensable ingredient of language teaching profession. Consistent with Isazadeh, Afzali, and Basir (2017) who maintain that the last decades have been years of research in language teaching and education, and a plethora of language teaching approaches, methods, and procedures since 1950s up to now reveals that applied linguistics has been one of the most intensively studied disciplines, Khodadady and Shayesteh (2016) declare that the bond between language teaching and textbooks is yet a new topic popped up recently. Meanwhile, it is daunting to define functions of the ELT textbooks impeccably and unerringly (Garinger, 2002). Some theorists assert that textbooks still act an irrefutable part in ELT curricula everywhere in the world (Davari \& Moini, 2016; Dendrinos, 1992; Hamidi, Bagheri, Sarinavaee, \& Seyyedpour, 2016; Williams, 1983, to name a few), especially in EFL contexts (Bagheri, Zendehboudi, Mehr, et al., 2015). The school textbooks involve guidelines and tips that will help both teachers as in the teacher's manual and students (Allehyani, et al., 2017a). English language teaching textbooks in general and English for Specific purposes (ESP) ones in particular are among the most central elements in any educational system (Ebadi \& Naderifarjad, 2015).

Nonetheless, ELT textbook use has both its pluses and minuses. While for the advocates textbooks are useable, worthwhile, and laborsaving (Brumfit, 1980), they remain superficial in terms of coverage and incapable of meeting the students' miscellaneous and wide-ranging needs as termed by those against the coursebooks (Tomlinson, 2001). In the face of such squabble, it is far and wide approved that textbooks are irreplaceable in both language learning and teaching (Cunningsworth, 1995; Dubin \& Olshtain, 1986, O’Neil, 1982; Sheldon, 1988) implying that, their pluses overweigh their minuses. Although Allwright (1981) takes issue with the restricted role of textbooks posing that a prescribed textbook would fail to exclusively help manage language learning, he demonstrates the textbook lessons as an interaction between the teacher, learners, and materials. Finally, he admits that such interaction enhances the opportunities to learn, and this adds to the benefits of the textbooks as teaching materials. Figure 1 represents the mentioned interaction.

With reference to positive and advantageous role of ELT textbooks globally, this research has endeavored to present a succinct review from the last few decades to better reveal the emphasis laid to ELT materials and textbooks during the past and present eras. During the 1980s, textbooks were 


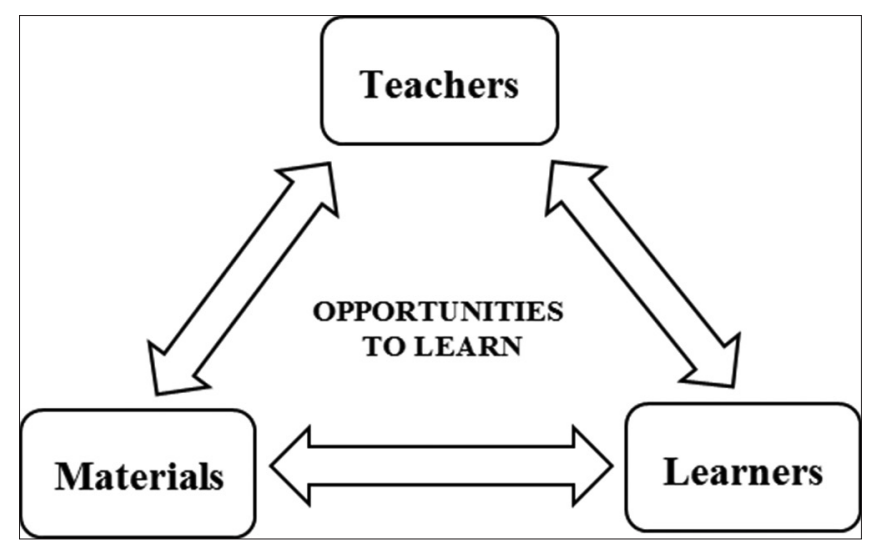

Figure 1. Interaction between teachers, learners, and materials (Allwright, 1981)

considered as being sensitive to students' needs and efficient for both saving the time and expenses (O’Neill, 1982), as the tangible element while providing a language course face validity (Dubin \& Olshtain, 1986), while guaranteeing uniformity and accountability (Prabhu, 1987), and as the heart of English language courses (Sheldon, 1988), improving students' capabilities linguistically and communicatively (Sheldon, 1987). Nunan (1988) pronounces that textbooks are the most fundamental components in ELT curriculum lubricating the learning wheels.

During the 1990s, textbooks were said to organize what is to be taught and learned, while being used for some purposes such as to study the subject (Harmer, 1991), or a resource or guide to language learning and teaching (Asher, 1994: Harmer, 1991), or for instruction or information (Asher, 1994). For Richards (1993), textbooks are resource books rather than course book, and also a trainer for a novice teacher; an authority in that it is reliable, valid, and written by experts. Textbooks for Hutchinson and Torres (1994) are worldwide teaching components without which the teaching and learning conditions would remain incomplete, playing a fundamental role in innovation, supporting teachers and introducing new methodologies, providing the necessary input into lessons, as well as being an exceptional tool for efficient and ongoing change, concluding that they are successful in fulfilling diverse needs emergent from the classes and their wider context. ELT textbooks were reported as influential resources for self-directedness in language education, a source of simulation and ideas, a syllabus by itself, and a big provision for inexperienced instructors. Brown (1995) considers them as a basis of language, supporting the learning, motivating the learners, providing stimulation, while being a reference. They provide a framework, readymade texts and tasks, a syllabus for language content, and useful guide for inexperienced teachers (Ur, 1996). Textbooks are realizations and determinants of the methods (Vassilakis 1997), while playing a prominent role in the teaching and learning processes, acting as an instructor, as a roadmap, in addition to being a resource, a trainer, an authority, a de-skiller and an ideology (Cortazzi \& Jin, 1999), a tool and a tutor, a guidebook and a gauge (Kulm, Roseman, \& Treistman, 1999).

During the 2000s, the textbooks still held the credit and its use was extensively favored. Grey (2000) defined them as ambassadorial cultural artifacts, and useful for stimulating cultural discussions and debates, and a reciprocal flow of data while Graves (2000) considered them to be a syllabus and a road map of the course. Byrd (2001) claims ELT textbooks represent the thematic/topic content and linguistic content while Tomlinson (2001) proposes that textbooks provide consistency, systematicity, cohesion, continuation, and progression. Textbooks were assumed to lower preparation time and provide ready-made activities (Garinger, 2001) and to set the direction and content while determining how the lesson should be taught (McGrath, 2002). Richards and Renandya (2002) believe textbooks have a role in social routinization. Textbooks were containers of vocabulary and sources for words (Catalán \& Francisco, 2008; Thornnbury, 2002), the next imperative element in after the teacher, serving for learners as the input (Riazi, 2003), mirroring the source culture and cultural values and being an international language (Aliakbari, 2004; Feng \& Byram, 2002). Textbooks are said to be as language inputs delivered in the classes (Murakami, 2009; Nooreen \& Arshad, 2005; Richards, 2007). Textbooks are frequently reported as references enabling students to revise and work on consolidation (Mukundan, 2004). For Çakit (2006), they manage the interaction between learners and teachers, while saving time, giving direction to the lessons, as well as providing confidence and security for teacher. Furthermore, they make the leap from intentions to classroom activities (Schmidt, McKnight, \& Raizen, 2007), providing an unblemished framework in which progress and goals are provided to both the learners and the teachers (Jeyachandra, 2009), and a model of English for students (Murakami, 2009).

In the last few years, again Parrish (2004) considers the textbooks as tools helping the instructors to attain a well-organized, dependable and commonsensical progress in classrooms while minimalizing their preparation time and declare that textbooks are a great guide for inexpert teachers. Textbooks constitute a significant genre, serving to socialize the readers into a particular ideology and worldview (Shardakova \& Pavlenko, 2004). Richards (2010) declares that textbook is the chief source of exposure the language for EFL students. Tok (2010) considers them as a framework whereby the teachers could fulfill the course objectives and as a guide to conduct lessons, and a source of input while for Najafi Sarem et al. (2013) they are as the heart of education. They guide the teachers in delivering their contents in classroom and a framework for learners to organize their learning (Dalim \& Mubarrak, 2013), and are the best tool to properly implement the school curricula (Mahmood, 2010), guiding teachers in designing the courses and activities, while being sources to deliver the knowledge to students more easily and systematically (Ahour \& Ahmadi, 2012; Ghufron \& Saleh, 2016a; Ghufron \& Saleh, 2016b; Karimi, Kargar, \& Behjat, 2015; Nazeer, Shah, \& Sarwat, 2015; Naseem, Shah, \& Tabassum, 2015), and being considered as commodities, political objects, and cultural representations (Mohammadi \& Abdi, 2014). Depending on their provisions, textbooks would either encourage or dishearten the students but they majorly support them and their teachers, provide them consistency (Zohrabi, Sabouri \& Kheradmand, 2014). Richards and Rod- 
gers (2014) declare materials encompass objectives, content, learning activities, and learner and teacher roles. Moghtadi (2014) considers textbooks as imperative resources which enable the teachers to help their learners acquire numerous subjects, among them English. Moreover, they are the most important teaching tool used formally and informally as well as being effective in self-study by learners (Ahmed, Yaqoob, \& Yaqoob, 2015), playing several roles in ELT curriculum, promoting teaching and learning (Ahmadi \& Derakhshan, 2016), and being sources of assistance for learners in leaning L2 (Hamidi, et al., 2016). For Kraishan and Almaamah (2016), they can assist teachers and students in addition to promoting teachers' development. Saadipour and Shakouri (2016) assert that textbooks have very profound influence on both language teaching and learning, providing the required contents and activities.

Finally, in the most recent time, textbooks have been given more heeds even more than before, considering them to have conspicuous merits. Aghagolzadeh and Davari (2017) declare that ELT policies have to be recognized by investigating diverse elements, among which ELT textbooks. Considering the textbooks, then, Gebregeorgis (2017) accentuates that textbooks are not only meant to deliver subject knowledge but also to convey universal and community-specific values. Textbooks are teaching-learning resources containing a series of texts and images aiming at certain educational outcomes, convey knowledge, attitudes and behaviors. Son and Diletti (2017) assert that some factors affect student learning and they are the curriculum as a whole and the curricular materials available, including textbooks. For Besharati and Mazdayasna (2017), textbooks are key factors to make decisions and judgments, while being the central sources of input for the learners, accentuating that without appropriate textbook, teaching learning situation is imperfect. In the current era, yet, Allehyani et al. (2017b) define textbooks as artificial materials designed for pedagogical purposes, which emphasize teaching linguistic structure (grammar and vocabulary as the main part of learning English). On the other hand, Klanawong (2017) announces that coursebooks are the most reliable resource for nonnative English speakers.

Having considered all the advantages and remunerations considered by quite a considerable number of authors over the last four decades, it can be concluded that the textbook is still an important component of ELT all over the world. Although in some parts of the world, teachers can freely select the books, most of them use textbooks which are either recommended or prescribed to them. Nonetheless, coursebooks have proved to be useful and efficient irrespective of being prescribed or selected by the teachers. Accordingly, this is the textbook which controls the teacher and students alongside the dynamics of the classroom. For this reason, great attention needs to be given when selecting the most suitable textbooks (Besharati \& Mazdayasna, 2017). As confirmed by Najafi Sarem et al. (2013), such a goal cannot be achieved immediately as it necessitates cautious analysis and investigation. Although the ELT related literature abounds with emphasis given to interminable merits of language textbooks, still the compiled textbooks, especially the ones prescribed in educational systems have to be evaluated and assessed to confirm whether they fulfil the objectives they are meant for or not, as it is said no perfect textbook exists but we are supposed to select the most appropriate textbooks which better cater the needs of certain students. The next section elaborates on evaluation in education in general, followed by another section dealing with textbook evaluation and necessity of evaluation.

\section{NATURE OF EVALUATION IN EDUCATION}

Generally speaking, evaluation refers to systematically collecting data with the intention of making paramount decisions. To suit this purpose, evaluation then includes certain procedures to obtain data adequate enough about a course or curriculum leading in their improvements. In practice, it targets at acquiring formal inquiry in any organization to realize whether the objectives are fulfilled; otherwise, the evaluated initiatives would be planned to be boosted (Hamidi, Montazeri, Alizadeh, \& Rezaie, 2015). As for language teaching and learning, evaluation denotes a method of collecting information by miscellaneous tools from different sources with the intention of decision making as regards the ELT framework and education (Kiely, 2009). This is all undertaken to bring about enhancement to a course of study as well as yielding reasonable results. Hence, program evaluation can be referred to as a type of inquiry that designates accomplishments related to a certain course, devising methods whereby additional improvement could emerge. Moreover, evaluation ascertains the quality and enhancement as well as establishing a discussion with respect to the courses leading to continual upgrading of learning prospects (Kiely, 2009). In addition to influencing the learning progression, evaluation is able to bring teacher development. As defined by Rea-Dickens and Germaine (1992), evaluation dynamically explores the appropriateness and appositeness of a present initiative. Indeed, evaluation is to be regarded as a valuable tool for instructors and material developers as one underpinning constituent in developing innovations and modifications in any educational context (Najafi Sarem et al., 2013). It is acknowledged by Naseem, Shah, and Tabassum (2015) that evaluation is an influential tool for enhancing the education quality and by doing so is an undeniable component of the education-related processes. Evaluation is an organized way of collecting and interpreting information meant for future decision making purposes (Nazeer, Shah, \& Sarwat, 2015).

\section{TEXTBOOK EVALUATION: JUSTIFICATION OF THE NEED}

Textbook evaluation is a major area addressed by language experts and curriculum designers. For the purpose of selecting an efficient and appropriate textbook, evaluation of the materials becomes a mandatory process with respect to definite guidelines and criteria. Ahmadi and Derakhshan (2015) confirm that textbook evaluation has been elaborated on remarkably during the two past decades, and that such evaluation has an indispensable part in implementing a textbook in any school (Çakit, 2006). In order for the textbooks to 
accomplish the aim of conveying the necessary intended information, they are expected to have definite features (Najafi Sarem et al., 2013). In this regard, throughout the last decades, textbook evaluation was emphasized for the thorough analysis of the textbooks to ascertain their effectiveness and expediency. Henceforth, it can be stated that the textbooks significantly affect the way the content is delivered (Najafi Sarem et al., 2013) and they still stand paramount in learning English in the classroom, although the accessibility to many learning tools has expanded (Allehyani, et al., 2017a; Samadikhah \& Shahrokhi, 2015). Literature is replete with both emphasizing the prominence of ELT textbooks and the urge to evaluate such textbooks. In practice, evaluation varies depending on the intended objectives, such as curriculum evaluation or textbook evaluation (Nazeer, Shah \& Sarwat, 2015).

On a general basis, thanks to different versions of English teaching materials available to us, it is obviously indispensable to evaluate and choose a high level and quality textbook facing disparate editions (Dalim \& Mubarrak, 2013; Klanawong, 2017; Kraishan \& Almaamah, 2016; Sun Hao, 2017). It is also underscored by Margana and Widyantoro (2017) that English textbooks clearly leads to better accomplishment of the language on condition that they are well developed; otherwise they only become obsolete. Indeed, selecting a good textbook that suits the learning context and curriculum is challenging for schools (Klanawong, 2017). Despite much research done on language learning textbooks, there still exist several questions unanswered about what these textbooks' contents are about (Khodadady \& Attaran, 2017). Evaluating EFL or ESL textbooks in any educational program can be of utmost importance. Nevertheless, to provide a meticulous evaluation of a textbook, considering all aspects of its language including semantic, syntactic, and also parasyntactic ones and then examining their values and socio-cultural aspects would be indispensable. Besharati and Mazdayasna (2017) hold that the textbooks should have an appropriate design to meet learners' language learning needs and they should be appraised in face of their adequate coverage of the intended materials.

More specifically, some scholars have advised why textbook evaluation has to be undertaken. Apart from evaluating to realize whether they accomplish the aim of conveying the knowledge (Najafi Sarem et al., 2013; Schmidt, et al., 2007), textbooks are evaluated so that the teachers would find out if they effectively suit their purposes while using the textbooks (Riazi \& Mosalanejad, 2010; Kulm, et al., 1999). Other reasons include checking their appropriacy in a given context with wide and contextually relevant criteria to meet students' contextual needs and expectations (Farzaneh, Kohandani, \& Nejadansari, 2014; Shah, Ahmed, \& Mahmood, 2014), matching learners' needs to available solutions (Akbari \& Pourabbas, 2015; Chowdhury, 2016; Grant, 1987; Salehi \& Khadivar, 2015; Tok, 2010), identifying textbooks' productivity and value as regards the aims, principles, or norms (Salehi, Khadivar, Babaee, \& Singh, 2015), establishing discrimination between all offered textbooks on the market (Miekley, 2005; Sheldon, 1988), implementing new coursebooks and identifying minuses and pluses in certain textbooks being in use (Cunningsworth, 1995), and for conducting action research (Tomlinson, 1996). Furthermore, it is proposed that textbook evaluation leads to teachers' development and professional growth (Cunningsworth, 1995), as well as upsurge in students' attainment and success of educational programs (Genesee, 2001), and promoting the teachers' awareness to set requisites. Considering some of the reason behind textbook evaluation, what matters now is how to conduct textbook evaluation and which method to adopt. It was earlier discussed that the nature of evaluation very much depends on the objectives the educators have in mind. The next section briefly presents the most widespread and common approaches adopted when ELT textbook evaluation is planned.

\section{COMMON APPROACHES FOR EVALUATING ELT TEXTBOOKS AND MATERIALS}

When it comes to textbook evaluation, there are miscellaneous proposed approaches and methods. In this research, the most widely-used ones are summarized as follows:

\section{The Impressionistic, Checklist, and In-depth methods}

Textbook analysis can be undertaken via three chief methods: impressionistic, checklist, or in-depth methods (McGrath, 2002). Widodo (2015) reports that the impressionistic method means attaining a general synopsis of the contents presented in the coursebook. In details, the impressionistic method deals with analyzing a textbook based on a general impression obtained by means of checking the textbook contents in view of organization, layout, the presented topics as well as the visuals, and so forth (Montasser, 2013). Nonetheless, such a method is claimed to be inadequate while it but could be integrated with another method to help gain more precise information about the textbooks being analyzed. Another recognized method is named the checklist method whereby the textbook is assessed against certain benchmarks (Çakit, 2006). By employing a checklist, it would be then easier to establish comparison among diverse materials (Montasser, 2013). Widodo (2015) highlights that by using a checklist we compare, identify, or verify. As a rather easy method, an evaluation checklist introduces us a list of criteria considered for any efficacious learning and/or teaching materials. Evaluators can be the teachers, researchers, or even the students who can rate the quality of the given material according to the mentioned criteria (Soori, Kafipur, \& Soury, 2011). A third distinguished method is the in-depth method which provides a vigilant scrutiny of the representative aspects; for instance, we are able to assess the design of a specific unit and/or an exercise, or the presentation of certain language elements (Montasser, 2013). Widodo (2015) reports that this method elaborates on students' needs, their attitudes towards learning, besides the practical teaching-learning approach.

\section{Predictive Evaluation vs. Retrospective Evaluation}

Predictive evaluation is used for decision making as regards what materials to use and determining which materials are 
best suited to the considered objectives and is meant for scrutinizing the future or potential of a certain textbook before adopting it. Moreover, in-use evaluation refers to the assessment of a textbook at the time of use which is sometimes incorporated with retrospective evaluation to realize if the textbooks, which have been already used, have worked out for the determined objectives (Cunningsworth, 1995; Ellis, 1997; Mohammadi \& Abdi, 2014). It is proposed that predictive evaluation can be undertaken via two distinct models, namely the implicit or explicit models. The former one is based on impressions and is pertinently termed the impressionistic model (discussed earlier). Yet, this method is disadvantaged with its incapability of team evaluation which is a problem when many teachers use the same textbook and they need to decide on it together. This is why the explicit model stands superior especially appropriate for team evaluations, which is typically accomplished by means of a checklist (discussed earlier) (Byrd, 2001; Cunningsworth, 1995; Skierso, 1991).

A retrospective evaluation is indeed determining the validity of a predictive evaluation and the ways to enhance the predictive instruments for future use (Ellis, 1997). Yet, both predictive and retrospective evaluations seek out to make both the teaching and learning environments more efficient. Hitherto, the focus of textbook evaluation has been mostly on predictive evaluation i.e. selection of the textbooks (Mukundan, 2010; Nunan, 1988) implying that teachers are even unaware of the retrospective type of assessment as a continuing one being conducted after the selection of the textbooks. Adopting the prospective evaluation has been particularly recommended for the countries in which the textbooks are prescribed by Ministries of Education because this evaluation enables reporting the feedback concerning a given textbook to the central authority; this definitely allows revising the textbooks accordingly (Mukundan, 2010). Considering the retrospective evaluation, Mukundan (2004) proposes a composite framework claiming that such evaluation is a process continuing for a term/semester length and then it can be adopted while the textbook is in use. This framework assumes better evaluation by triangulation of data obtained via diverse instruments in preference to one. This could be a combination of the concordance software, a reflective journal, as well as a checklist.

\section{Macro-evaluation vs. Micro-evaluation}

In addition to the predictive versus retrospective evaluation, Ellis (1997) suggests the micro-evaluation versus macro-evaluation. While in the former type the teacher chooses a specific teaching task of interest and makes it undergo a detailed empirical evaluation, the latter refers to an inclusive appraisal to understand if the whole textbook is efficient. Although it is admitted that planning and collecting the required information for macro-evaluation is daunting, a sequence of micro-evaluations could be a source for a succeeding macro-evaluation. In details, a micro-evaluation might be used independently while serving as a useful and appropriate means for empirically undertaking textbook evaluation. Ellis (1997) avers that a micro-evaluation of textbook can be probably done with regard to task which is a term extensively employed in ELT (e.g. Prabhu 1987; Nunan 1998).

\section{Pre-Use, In-Use, Post-Use evaluations}

Tomlinson (1998) delineates the materials evaluation is a systematic judgment regarding the materials value with respect to the materials' objectives and the pupils making use of such materials. Furthermore, Cunningsworth (1995) and Tomlinson (1998) categorize the evaluation into pre-use, while-use or in-use, and after-use types which is dependent on the aims of evaluation. While Tomlinson (1998) claims that the pre-use type of evaluation revolves around the prediction of the potential values, Cunningsworth (1995) accentuates that the objective of a pre-use evaluation is to examine the course book's future or potentiality, as called predictive by Ellis (1997). Moreover, Tomlinson (1998) mentions that while-use evaluation concentrates on cognizance plus defining students' dealing with the materials; yet, Cunningsworth (1995) calls this type in-use evaluation. Finally, after-use evaluation is proposed to determine what happened on account of using the instructional materials (Tomlinson, 1998), and Cunningsworth (1995) names this type as post-use evaluation affirming that it allows retrospective evaluation. In this regard, Post-use evaluation seems to be beneficial for recognizing the merits and demerits of a certain textbook following its continual use. Post-use evaluation is also valuable in determining if the evaluated textbook is good enough for future use.

\section{Bloom's Taxonomy}

In addition to the previously reported criteria, Bloom's taxonomy of learning objectives (1956) has been used by several scholars to evaluate ELT textbooks (Aviles, 2000; Riazi \& Mosalanejad, 2010; Sultana, 2001, to name a few). It is possible to employ this taxonomy in the broader education context with the intention of assisting experienced and inexperienced teachers with a focus on critical thinking (Aviles, 2000). For instance, in a research conducted by Sultana (2001), it was revealed that less than half of the lesson objectives for the new teachers were at the knowledge level i.e. the lowermost cognitive category whereas a very low percentage $(3.2 \%)$ were attributed to the highest level. The research by Riazi and Mosalanejad (2010) similarly exhibited that the dominance of lower-order cognitive skills in all English textbooks in Iranian senior high school and pre-university. Depending on the scopes and objectives of the research, this taxonomy could be also adopted to evaluate the textbooks revealing results which can help decide how a certain textbook's performance is.

\section{A Benchmarks-Based Approach: A Qualitative Method}

Since the birth of Project 2061 which is a long-time science education reform initiative proposed by the American Association for the Advancement of Science, there has been a tendency toward textbook evaluation based on how 
close they stand to defined benchmarks. The primary stage in benchmarks-based method is to recognize the learning goals. This helps decide whether the textbooks match such goals or not. Such a procedure is applicable to any K-12 system subjects, such as English, that enjoy a set of approved distinct learning goals (Kulm, et al., 1999). It is stated that such learning goals are expected to determine what all the learners would learn after all while having unblemished, detailed, and unequivocal purpose. In further details, Dalim and Mubarrak (2013) recommend that in opposition to a shallow consideration of numerous learning goals, this project 2061 assumes a painstaking inspection of the quality of a textbook's dealing with only some wisely chosen learning goals would be more enlightening. In other words, it would be easier to determine the advantages and setbacks of the textbook's instructional design and support by adopting the principles of benchmarks-approach through investigating a material's dealing with a few learning goals. While trying to establish conclusion if the studied textbook truly embraces the specified learning goals, a couple of notions are kept in mind, namely substance and sophistication. This helps conclude if the activities in the textbook address the specified substance associated with a learning goal or if there is only a topic match (Dalim \& Mubarrak, 2013). What exhibited in Figure 2 is a summary of the widely-used approaches or methods for material and textbook analysis presented in the relevant literature, although there are quite a few other methods which were not discussed here due to the scope of this research as well as less popularity for such methods.

\section{CONCLUDING REMARKS: WHERE THE FUTURE TAKES US}

This research highlighted that the ELT textbooks are the most relevant source of learning English, as they are useable, expedient, and laborsaving that fulfill an extensive range of needs, among which to impart the knowledge to the learners, to enhance opportunities to learn as well as students' linguistic and communicative abilities, to present the source of input, either linguistic, or cultural and social, a framework, and to serve as a guide for learners and instructors, especially the inexperienced ones as well as a syllabus for language content. Textbooks could be invaluable sources of simulation and ideas and sources for self-directed learning. Although it is literarily accepted that the content of most textbooks is perishable, the tools of self-directness provided by the textbooks would serve one well over time. In a nutshell, an ELT textbook is not merely a set of sheets of paper fastened together to hinge at one side, but is the beating heart of any education system whereupon the whole learning revolves.

Notwithstanding their prominence in language classes, there is a dearth of research focusing on textbook selection. On the whole, the current state of affairs is less than satisfactory implying that further work is required (Nicholls, 2003) and because so far the researchers have failed to help educators, practitioners, and the related stakeholders to decide more wisely to find and adapt the materials needed for their classes (Soori, et al., 2011). It is approved that there is no perfect and faultless textbook (Pourahmad, Naderi, \& Heidarpoor, 2015), urging the teachers to adopt supplemental materials consistent with their needs (Ansary \& Babaii,

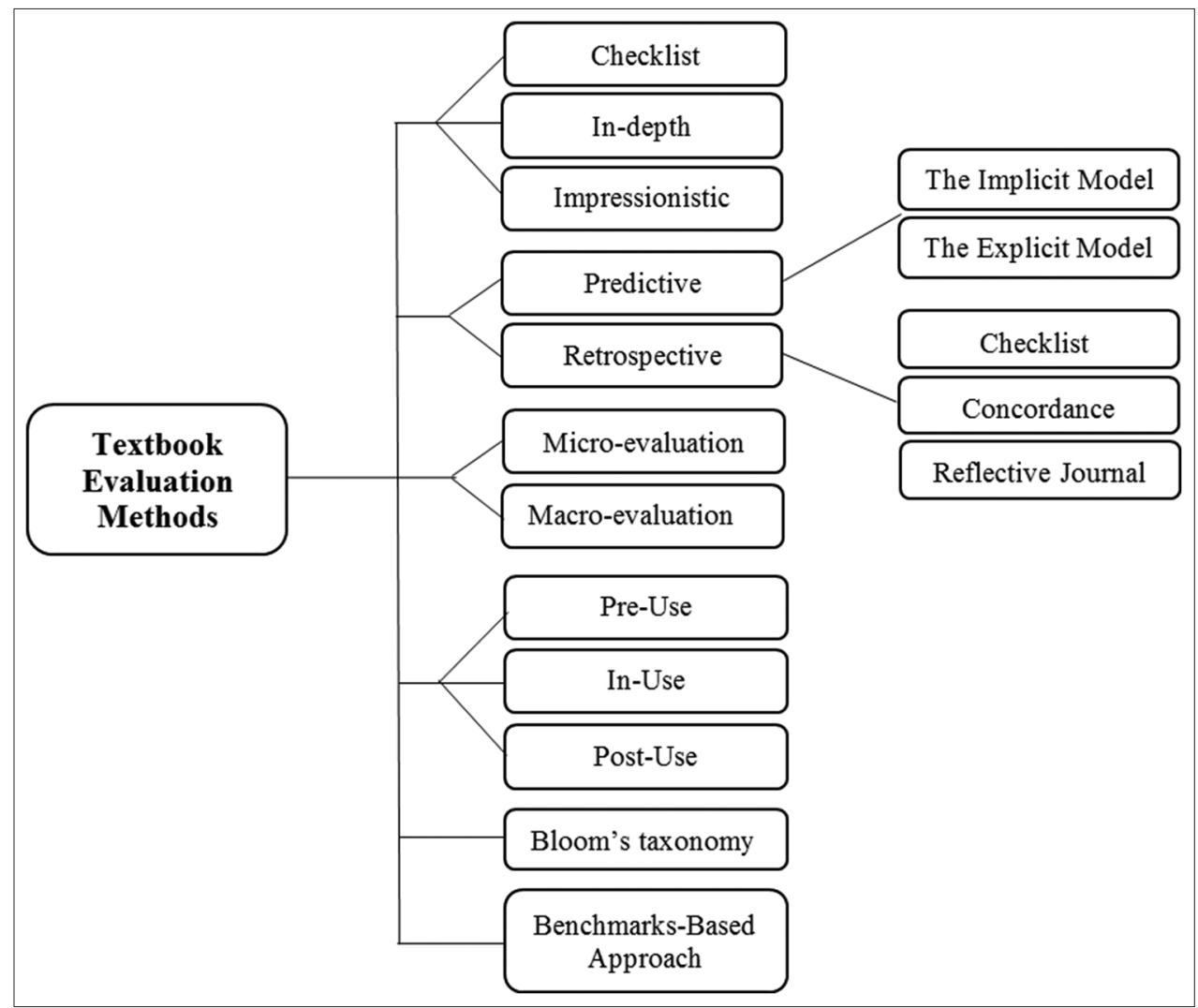

Figure 2. The Most Widely-Adopted Textbook Evaluation Methods 
2002). This brings us to the necessity of textbook evaluation (Khoo \& Knight, 2015; Nazeer, Shah, \& Sarwat, 2015) to warrant ELT textbooks would efficiently lead to fulfilling the intended objectives (Chowdhury, 2016; Langroudi \& Behrozi, 2015), and simultaneously be workable economically (Maleki et al, 2014). Ahmed, Yaqoob, and Yaqoob (2015) assert that textbook evaluation implies compiling textbooks in accordance with reliable examination. Ghufron and Saleh (2016a) confirm that textbook evaluation would benefit teachers both in developing themselves and acquiring worthwhile visions concerning the materials' nature.

It is recommended that scrupulous evaluation has to be conducted to boost the textbooks' quality (Khodadady \& Shayesteh, 2016; Naseem, Shah, \& Tabassum, 2015), especially during implementation, by outside consultants who were not part of the textbook development and selection process (Zewdie, 2014). This is to ensure whether they are in their right place for both learners and teachers to benefit from (Bagheri, et al. 2015); still, diverse methods could be adopted when it comes to textbook analysis depending on the scope and aim of the studies. Khoo and Knight (2015) confirm that both checklist approaches and non-checklist approaches (such as Corpus-based techniques, were recommended previously as attempts to determine the universal criteria. It is indispensable for the evaluator to take into account overall application of the materials with the intention of incorporating them with the overall syllabus. On occasion, it is undeniable for us to adapted the materials so that they would match the students' linguistic proficiency, or for any other reasons. Yet, it is asserted hereby that the motives to evaluate textbooks fluctuate diversely and the fact remains after all that any kind of evaluation should serve the betterment of learning outcome.

This paper underscores that the compiled textbooks, particularly the ones prescribed in Educational systems are required to be evaluated more practically to confirm whether they accommodate the needs they are meant for. Once the books are assessed, the areas where they are weak could be identified and by devising plans to overcome such detriments, the teachers would be able to enhance the learning outcomes by providing appropriate follow-up activities or extracurricular programs when using the textbooks. Due to the fact that most teachers are either unable to do predictive evaluation or are not given the chance to do so, retrospective type of evaluation can be of use to compensate for the weaknesses and shortcomings in forthcoming classroom use.

This paper has implications primarily for English language teachers by assisting them to select the most appropriate method of evaluation when they tend to assess the textbooks they are using. Moreover, educators, textbook compilers and curriculum designers could benefit from the findings of this research as they are introduced to the most common methods being in use for textbook evaluation. As it was emphasized, little scrutiny has concentrated on textbook evaluation and this paper is hoped to shed light on how textbook evaluation is practiced worldwide and stand as a comprehensive account of its kind by covering the textbooks evaluation practices for the last four decades.

\section{REFERENCES}

Aghagolzadeh, F., \& Davari, H. (2017). English Education in Iran: From Ambivalent Policies to Paradoxical Practices. In English Language Education Policy in the Middle East and North Africa (pp. 47-62). Springer International Publishing.

Ahmadi, A., \& Derakhshan, A. (2016). EFL Teachers' Perceptions towards Textbook Evaluation. Theory and Practice in Language Studies, 6(2), 260-267.

Ahmadi, A., \& Derakhshan, A. (2015). An Evaluation of the Iranian Junior High School English Textbooks. International Journal of English Language and Literature Studies, 4(1), 37-48.

Ahmed, M., Yaqoob, H., \& Yaqoob, M. (2015). Evaluation of Listening Skill of ELT Textbook at Secondary School Level. Advances in Language and Literary Studies, 6(3), 225-229.

Ahour, T., \& Ahmadi, E. (2012). Retrospective evaluation of textbook "Summit 2B" for its suitability for EFL undergraduate students. Journal of Educational and Social Research, 2(5), 195-202.

Aliakbari, M. (2004). The place of culture in the Iranian ELT textbooks in high school level. The Linguistic Journal, $1,1-14$.

Akbari, O., \& Pourabbas, H. (2015). Evaluation of Iranian Second-Grade High School English Textbook Based on Needs Analysis Approach. Journal of Applied Linguistics and Language Research, 2(5), 19-34.

Allehyani, B., Burnapp, D., \& Wilson, J. (2017a). The Place of Inner-Circle Culture in Saudi Secondary School Textbooks. International Journal of English and Education, 6(2), 1-12.

Allehyani, B., Burnapp, D., \& Wilson, J. (2017b). A comparison of teaching materials (school textbooks vs authentic materials) from the perspective of English teachers and educational supervisors in Saudi Arabia. International Journal of English Language and Linguistics Research, 5(2), 1-14.

Allwright, R. L. (1981). What do we want teaching materials for? 1. ELT journal, 36(1), 5-18.

Ansary, H., \& Babaii, E. (2002). Universal characteristics of EFL/ESL textbooks: A step towards systematic textbook evaluation. The Internet TESL Journal, 8(2), 1-9.

Asher, R.E. (Ed.). (1994). The encyclopedia of language and linguistics. Oxford: Pergamon Press.

Aviles, C. B. (2000). Teaching and testing for critical thinking with Bloom's taxonomy of educational objectives. (ERIC Document Reproduction Service No. ED446023).

Bagheri, M., Zendehboudi, K., Mehr, A. R., Teimouri, E., \& Tashakori, S. (2015). An In-depth Evaluation of the Textbook Prospect One. The Iranian EFL Journal April 2015 Volume 11 Issue 2, 88 - 94

Besharati, M.H., \& Mazdayasna, G. (2017). Investigating Iranian EFL students' attitudes concerning the newly developed ESP materials. Modern Journal of Language Teaching Methods, 7(5),45-58.

Brumfit, C. J. (1980). Seven last slogans. Modern English Teacher, 7(1), 30-31. 
Byrd, P. (2001). Textbooks: Evaluation for selection and analysis for implementation. Teaching English as a second or foreign language, 3, 415-428.

Çakit, I. (2006). Evaluation of the EFL Textbook "New Bridge to Success 3 " From the Perspectives of Students and Teachers (Unpublished MA Thesis). Middle East Technical University, Ankara, Turkey.

Catalán, R. M. J., \& Francisco, R. M. (2008). Vocabulary input in EFL textbooks. Revista Española De Lingüística Aplicada (RESLA), (21), 147-166.

Chowdhury, M. Y. U. K. (2016). Case Study of the Commercially Published ELT materials in Foundation of English Course Books 1 \& 2. IIUC Studies, 10, 173-182.

Cortazzi, M. (2000). Languages, cultures, and cultures of learning in the global classroom. Anthology Series-Seameo Regional Language Centre, 75-103.

Cunningsworth, A. (1995). Choosing your coursebook. Oxford: Heinemann.

Dalim, S.F. and Mubarrak, M. (2013). Quantitative method of textbook evaluation for chemistry (KBSM) Form 4 textbook. Proceeding of the International Conference on Social Science Research, ICSSR 2013 (e-ISBN 978967-11768-1-8). 4-5 June 2013, Penang, Malaysia. Organized by WorldConferences.net.

Davari, S., \& Moini, M. R. (2016). The Representation of Social Actors in Top Notch Textbook Series: A critical discourse analysis perspective. International Journal of Foreign Language Teaching and Research, 4(13), 69-82.

Dendrinos, B. (1992). The EFL textbook and ideology. Grivas.

Dubin. F. Olshtain, E. (1986). Course Design. Developing Programs and Materials for Language Learning. Cambridge: Cambridge University Press.

Ebadi, S., \& Naderifarjad, Z. (2015). Evaluation of EAP Textbooks: A Comparison between SAMT English for Medical Students and Oxford English for Career. Journal of Applied Linguistics and Language Research, 2(3), 133-149.

Ellis, R. (1997). The empirical evaluation of language teaching materials. ELT journal, 51(1), 36-42.

Farzaneh, N., Kohandani, M., \& Nejadansari, D. (2014). A textbook evaluation of socio-cultural contexts in top notch series. Procedia-Social and Behavioral Sciences, 98, 472-481.

Feng, A., \& Byram, M. (2002). Authenticity in College English textbooks-An intercultural perspective. RELC Journal, 33(2), 58-84.

Garinger, D. (2002). Textbook selection for the ESL classroom. Center for Applied Linguistics Digest. Retrieved in June 2016 from: http://www.cal.org/ericcll/digest/0210garinger.html.

Gebregeorgis, M. Y. (2017). Peace values in language textbooks: the case of English for Ethiopia Student Textbook. Journal of Peace Education, 14(1), 54-68.

Genesee, F. (2001). Evaluation. In R. Carter, \& D. Nunan (Eds.), The Cambridge guide to teaching English to speakers of other languages (pp. 144-150). Cambridge: Cambridge University Press.

Ghufron, M. A., \& Saleh, M. (2016a). Designing a model of research paper writing instructional materials for ac- ademic writing course: Textbook evaluation. Language Circle: Journal of Language and Literature, 10(2), 113-123.

Ghufron, M. A., \& Saleh, M. (2016b). Evaluating academic writing textbook: Teachers' and students' perspectives. Arab World English Journal, 7(1), 326-340.

Grant, M. (1987). Making the most of your textbook. London: Longman.

Graves, K. (2000). Designing language courses: A guide for teachers. Boston: Heinle.

Haghverdi, H. R. \& Ghasemi, B. (2013). An evaluation of American English File series. Iranian Journal of Research in English Language Teaching, 1(2), 83-97.

Hamidi, H., Bagheri, M., Sarinavaee, M., \& Seyyedpour, A. (2016). Evaluation of Two General English Textbooks: New Interchange 2 vs. Four Corners 3. Journal of Language Teaching and Research, 7(2), 345-351.

Hamidi, H., Montazeri, M., Alizadeh, K., \& Rezaie, J. (2015). A comparative evaluation and analysis of two general English textbooks: Four Corners 1 vs. Top Notch Fundamentals A. Theory and Practice in Language Studies, 5(6), 1192-1199.

Harmer, J. (1991). The Practice of English Language Teaching. London: Longman.

Haycraft, J. (1978). An introduction to English language teaching. Longman Publishing Group.

Hutchinson, T., \& Torres, E. (1994). The textbook as agent of change. ELT journal, 48(4), 315-328.

Hutchinson, T. \& Waters, A. (1987). English for Specific Purposes: A learning-centred approach. Cambridge: Cambridge University Press.

Isazadeh, P. \& Afzali, P., \& Basir, Z. (2017) Teaching English in the EFL context of Iran: Perceptions, implications and restrictions. Modern Journal of Language Teaching Methods, 7(2),89-93.

Jamalvandi, B. (2014). ELT Textbook Evaluation in Iran, New Insights. European Online Journal of Natural and Social Sciences, 3(4), 1068-1078.

Jeyachandra, S. (2009). Textbook Analysis of English for Engineers. Language in India, 9(10), 187-224.

Karimi, S., Kargar, A., \& Behjat, F. (2015). An evaluation of commonly used general English textbooks of Iranian university contexts. Modern Journal of Language Teaching Methods, 5(3), 257-269.

Khodadady, E., \& Shayesteh, S. (2016). Cultural and linguistic imperialism and the EIL movement: Evidence from a textbook analysis. Issues in Educational Research, 26(4), 604-622.

Khodadady, E., \& Attaran, A. (2017). Evaluation of "Ready for First Certificate of English": Microstructural Approach. International and Multidisciplinary Journal of Social Sciences, 6(1), 1-22.

Khoo, H. S., \& Knight, P. (2015). Teachers' Evaluation of KBSM Form 4, 5 English Textbooks Used in the Secondary Schools in Penang, Malaysia. Advances in Language and Literary Studies, 6(4), 128-150.

Kiely R. (2009). Small answers to the big question: Learning from language program evaluation. Language Teaching Research, 13(1), 99-116. 
Klanawong, S. (2017). A Study of Reading Questions in High School English Textbooks and National Tests. The New English Teacher, 11(1), 44-68.

Kraishan, O. M., \& Almaamah, I. (2016). Evaluation of the Third Class Science Text Book from the Teacher's Perspective at Madaba Municipality. International Education Studies, 9(3), 123-130.

Kulm, G., Roseman, J., \& Treistman, M. (1999). A benchmarks-based approach to textbook evaluation. Science Books \& Films, 35(4), 147-153.

Langroudi, J., \& Behrozi, E. (2015). Evaluation of an ESP Textbook for the Students of Accounting. The Iranian EFL Journal April 2015 Volume 11 Issue 2, 2(5), 109-125.

Litz, D. R. (2005). Textbook evaluation and ELT management: A South Korean case study. Asian EFL journal, 48, 1-53.

Mahmood, K. (2010). Textbook Evaluation in Pakistan: Issue of Conformity to the National Curriculum Guidelines. Bulletin of Education and Research, 32(1), 15-36.

Maleki, A., Mollaee, F., \& Khosravi, R. (2014). A content evaluation of Iranian pre-university ELT textbook. Theory and Practice in Language Studies, 4(5), 995-1000.

Margana, M., \& Widyantoro, A. (2017). Developing English Textbooks Oriented to Higher Order Thinking Skills for Students of Vocational High Schools in Yogyakarta. Journal of Language Teaching and Research, 8(1), 26-38.

McGrath, I. (2002). Materials Evaluation and Design for Language Teaching. Edinburgh: Edinburgh University Press.

Miekley, J. (2005). ESL textbook evaluation checklist. The Reading Matrix, 5(2). Retrieved from: http://www. readingmatrix. com/reading_projects/miekley/project. pdf.

Moghtadi, L. (2014). Iranian high school EFL textbooks: Why they should be modified. International Journal of Language Learning and Applied Linguistics World, 5(2), 53-69.

Mohammadi, M., \& Abdi, H. (2014). Textbook evaluation: A case study. Procedia-Social and Behavioral Sciences, 98, 1148-1155.

Montasser, M. A. (2013). Developing an English language textbook evaluative checklist. IOSR Journal of Research \& Method in Education, 1(3), 55-70.

Mukundan, J. (2010). Evaluation of english language textbooks: Some important issues for consideration. Journal of NELTA, 12(1), 80-84.

Mukundan, J. (2004). Making textbook evaluation meaningful. ELT Matters, 2, 105-113.

Murakami, A. (2009). A corpus-based study of English textbooks in Japan and Asian countries: Multidimensional approach. Unpublished master's thesis. Tokyo: Tokyo University of Foreign Studies.

Najafi Sarem, S., Hamidi, H., \& Mahmoudie, R. (2013). A critical look at textbook evaluation: A case study of evaluating an ESP course-book: English for international tourism. International Research Journal of Applied and Basic Sciences, 4(2), 372-380.
Naseem, S., Shah, S. K., \& Tabassum, S. (2015). Evaluation of English textbook in Pakistan: A case study of punjab textbook for $9^{\text {th }}$ class. European Journal of English Language and Literature Studies, 3(3), 24-42.

Nazeer, M., Shah, S. K., \& Sarwat, Z. (2015). Evaluation of Oxon English Textbook Used in Pakistan Public Schools for $6^{\text {th }} \& 7^{\text {th }}$ Grade. Journal for the Study of English Linguistics, 3(1), 51-79.

Nicholls, J. (2003). Methods in school textbook research. International journal of historical learning, teaching and research, 3(2), 11-26.

Nooreen, N., \& Arshad, A. S. (2005). Examining the importance of EST and ESL textbooks and materials: Objectives, content and form. English for Specific Purposes World, 9(4). Retreived from http://www.esp-world.info/ Articles 9/textbooks.htm.

Nunan, D. (1998). The learner-centered curriculum. Cambridge: Cambridge University Press.

Nunan, D. (1988). Syllabus design. Oxford: Oxford University Press.

O’Neill, R. (1982). Why use textbooks?. ELT journal, 36(2), 104-111.

Parrish, B. (2004). Teaching Adult ESLA Practical Introduction. New York: McGraw Hill.

Pourahmad, A., Naderi, K., \& Heidarpoor, S. (2015). A Comparison between the New Version of Iranian High-School English Textbooks and the Internationally-Produced Top Notch Series: A Comparative Study. Modern Journal of Language Teaching Methods, 5(4), 31-43.

Prabhu, N. S (1987). Second Language Pedagogy. Oxford: Oxford University Press.

Riazi, A. M. (2003). What Textbook Evaluation Schemes Tel Us? A Study of the Textbok Evaluation Schemes of Three Decades, in W. A. Renanda. (ed.), Methodology and Materials Design in Language Teaching, Singapore: SEAMEO Regional Center, pp. 52-68.

Riazi, A. M., \& Mosalanejad, N. (2010). Evaluation of learning objectives in Iranian high-school and pre-university English textbooks using Bloom's taxonomy. TESL-EJ: The Electronic Journal for English as a Second Language, 13(4).

Richards, J. C. (2010). Competence and performance in language teaching. RELC journal, 41(2), 101-122.

Richards, J. C. (2007). Curriculum development in language teaching. Eighth printing. New York: Longman.

Richards, J. C. (1993). Beyond the text book: The role of commercial materials in language teaching. RELC journal, 24(1), 1-14.

Richards, J. C., \& Renandya, W. A. (2002). Methodology in language teaching: An anthology of current practice. Cambridge university press.

Richards, J. C., \& Rodgers, T. S. (2014). Approaches and methods in language teaching. Cambridge university press.

Saadipour, A., \& Shakouri, A. (2016). A Comparative Study of English Textbooks in Iranian Non-Profit Institutes and Schools. International Journal of Multidisciplinary and Current research, 4, 322-327. 
Salehi, H., \& Khadivar, Z. (2015). Evaluation of an ESP Medical Textbook: Instructors and Learners' Perceptions in Focus. International Education Studies, 8(7), 97-107.

Salehi, H., Khadivar, Z., Babaee, R., Singh, J., \& Kaur, H. (2015). An evaluating study on ESP medical textbook: instructors and learners needs analysis. English Language Teaching, 8(7), 142-151.

Samadikhah, M., \& Shahrokhi, M. (2015). A Critical Discourse Analysis of ELT Materials in Gender Representation: A Comparison of Summit and Top Notch. English Language Teaching, 8(1), 121-134.

Schmidt, W. H., McKnight, C. C., \& Raizen, S. (Eds.). (2007). A splintered vision: An investigation of US science and mathematics education (Vol. 3). Springer Science \& Business Media.

Shah, S. K., Ahmed, M., \& Mahmood, R. (2014). Representation of target culture in the ELT textbooks in Pakistan: Evaluation of "Oxford Progressive English" for cultural relevance. Journal of Education and Practice, 5 (13), 89-101.

Shannon, p. (2010). Textbook Development and Selection. International Encyclopedia of Education (Third Edition).

Shardakova, M., \& Pavlenko, A. (2004). Identity options in Russian textbooks. Journal of Language, Identity, and Education, 3(1), 25-46.

Sheldon, L. E. (1988). Evaluating ELT textbooks and materials. ELT journal, 42(4), 237-246.

Sheldon, L. E. (Ed.). (1987). ELT textbooks and materials: Problems in evaluation and development. Modern English Publications.

Skierso, A. (1991). Textbook selection and evaluation. Teaching English as a second or foreign language, 2, 432-453.

Son, J. W., \& Diletti, J. (2017). What Can We Learn from Textbook Analysis?. In What Matters? Research Trends in International Comparative Studies in Mathematics Education (pp. 3-32). Springer International Publishing. Soori, A., Kafipour, R., \& Soury, M. (2011). EFL textbook evaluation and graphic representation. European Journal of Social Sciences, 26(3), 481-493.

Sultana, Q. (2001). Scholarly teaching - Application of Bloom's taxonomy in Kentucky's Classrooms. Paper presented at the Third Annual Conference on Scholarship and Teaching, Bowling Green, KY. (ERIC Document Reproduction Service No. ED 471982.).

Sun Hao (2017). The Analysis and Evaluation of New Standard English Student's Book One. Campus English Magazine, 3, 3-3.

Thornbury, S. (2002). How to Teach Vocabulary. Harlow: Longman.

Tok, H. (2010). TEFL textbook evaluation: From teachers' perspectives. Educational Research and Reviews, 5(9), 508-517.

Tomlinson, B. (2011). Materials development in language teaching. Cambridge University Press.

Tomlinson, B. (1998). Materials development in language teaching. Cambridge: Cambridge University Press.

Tomlinson, B. (Ed.). (1996). Materials development in language teaching. Cambridge: Cambridge University Press.

Ur, P. (1996). A course in language teaching: practice and theory. Cambridge: Cambridge University Press.

Vassilakis, G. (1997). Materials and methods: Need they be in conflict? Paper presented by at the TESOL Greece Saturday seminar on Material Choice and Development in the EFL Classroom ( $9^{\text {th }}$ February).

Widodo, H. P. (2015). Textbook analysis on college academic writing. TEFLIN Journal, 18(2), 109-122.

Williams, D. (1983). Developing criteria for textbook evaluation. ELT Journal, 37(3), 251-255.

Zewdie, Z. M. (2014). Analysis of Grades 7 and 8 Physics Textbooks: A Quantitative Approach. American Journal of Educational Research, 2(1), 44-49.

Zohrabi, M., Sabouri, H., \& Kheradmand, M. (2014). Comparative study of Interchange1 and English book1 of Iranian high schools. Education International Journal of English, 3(2), 95-104. 